УДК 336.1.003.13

СВТУШЕНКО М. В. ${ }^{1}$

\title{
МЕТОДИ МЕНЕДЖМЕНТУ ЕВМ У ФІНАНСОВІЙ ДІАГНОСТИЦІ ЕФЕКТИВНОСТІ УПРАВЛІННЯ ВАРТІСТЮ СУБ'ЄКТІВ ГОСПОДАРЮВАННЯ
}

\author{
DOI: 10.32620/cher.2019.1.10
}

\begin{abstract}
Постановка проблеми. В умовах посилення невизначеності ринкового середовища, забезпечення стабільного відтворення вартості господарюючих суб'єктів актуалізує використання відповідних інструментів управління, зокрема, фінансової діагностики. Мета статті. Обгрунтувати доцільність впровадження методів менеджменту на основі очікувань (EBM) для здійснення фінансової діагностики ефективності діяльності господарюючих суб'єктів. Предметом дослідження $\epsilon$ теоретичні положення та методичні підходи до формування системи фінансової діагностики в управлінні вартістю суб'єктів господарювання з урахуванням ринкових очікувань. Методи, використані в дослідженні: наукового пізнання, індукції, систематизації та теоретичного узагальнення. Гіпотезою стало припущення, що врахування впливу ринкових очікувань в процесі управління підприємствами є основою розвитку методичних засад фінансової діагностики в управлінні вартістю господарюючих суб'єктів на основі використання методів менеджменту ЕВМ. Виклад основного матеріалу. На основі результатів дослідження запропоновані підходи та система показників щодо здійснення фінансової діагностики та оцінювання ефективності діяльності (операційної, фінансової, інвестиційної) господарюючих суб'єктів. Оригінальність та практичне значення дослідження полягає в обгрунтуванні методичного забезпечення фінансової діагностики орієнтованої на управління вартістю підприємств: методи менеджменту EBM, системи показників і критеріїв оцінювання економічно доданої вартості та ефективності діяльності. Висновки дослідження. Використання методів менеджменту ЕВМ і фінансової діагностики дозволяє визначати відхилення внутрішньої вартості від ринкової та приймати відповідні управлінські рішення щодо інвестицій.
\end{abstract}

Ключові слова:

фінансова діагностика, управління вартістю, господарюючі суб'єкти, менеджмент на основі очікувань (ЕВМ), ринкові очікування, ефективність діяльності, вартість.

\section{THE METHODS OF ECONOMIC MANAGEMENT IN FINANCIAL DIAGNOSTICS OF THE EFFICIENCY OF THE VALUE OF THE COST OF BUSINESS ENTITIES}

Formulation of the problem. In the conditions of increasing uncertainty of the market environment, ensuring the stable reproduction of the cost of economic entities, the use of appropriate management tools, in particular, financial diagnostics, is updated. The purpose of the research. To substantiate expediency of introduction of management methods on the basis of expectations (EBM) for carrying out of financial diagnostics of efficiency of activity of economic subjects. The subject of the research is the theoretical positions and methodical approaches to the formation of the system of financial diagnostics in the management of the cost of economic entities in the light of market expectations. Methods used in the research: scientific knowledge, induction, systematization and theoretical generalization. The hypothesis was that the consideration of the influence of market expectations in the process of enterprise management is the basis of the development of methodological principles of financial diagnostics in the management of the value of economic entities on the basis of the use of management methods of the EBM. Presenting main material. On the basis of the research results, the approaches and the system of indicators for the implementation of financial diagnostics and assessment of the effectiveness of activities (operational, financial, investment) of economic entities are proposed. The originality and practical value of the research is to substantiate the methodical provision of financial diagnostics of cost-oriented enterprises: the management methods of the EBM, the system of indicators and criteria for assessing the economically added value and efficiency of the activity. Conclusions of the research. The use of EBM management techniques and financial diagnostics allows you to determine the deviation of the internal cost from the market and make

${ }^{1}$ Свтушенко Марина Вікторівна, асистент кафедри «Корпоративні фінанси і контролінг», ДВНЗ «Київський національний економічний університеу імені Вадима Гетьмана», м. Київ, Україна.

Yevtushenko Maryna, assistant of Corporate Finance and Controlling Department, Kyiv National Economic University named after Vadym Hetman, Kiev, Ukraine.

ORCID ID: 0000-0002-0775-2737

e-mail:marinapanasyuk@ukr.net 
appropriate management decisions regarding investments.

Key words:

financial diagnostics, cost management, business entities, management based on expectations (EBM), market expectations, performance, value.

\section{МЕТОДЫ МЕНЕДЖМЕНТА ЭВМ В ФИНАНСОВОЙ ДИАГНОСТИКЕ ЭФФЕКТИВНОСТИ УПРАВЛЕНИЯ СТОИМОСТЬЮ СУБЪЕКТОВ ХОЗЯЙСТВОВАНИЯ}

Постановка проблемы. В условиях усиления неопределенности рыночной среды, обеспечения стабильного воспроизведения стоимости хозяйствующих субъектов актуализирует использование соответствующих инструментов управления, в частности, финансовой диагностики. Цель статьи. Обосновать целесообразность внедрения методов менеджмента на основе ожиданий (ЭВМ) для осуществления финансовой диагностики эффективности деятельности хозяйствующих субъектов. Предметом исследования являются теоретические положения и методические подходы к формированию системы финансовой диагностики в управлении стоимостью субъектов хозяйствования с учетом рыночных ожиданий. Мето$\partial b l$, использованные в исследовании: научного познания, индукции, систематизации и теоретического обобщения. Гипотезой стало предположение, что учет влияния рыночных ожиданий в процессе управления предприятиями является основой развития методических основ финансовой диагностики в управлении стоимостью хозяйствующих субъектов на основе использования методов менеджмента ЭВМ. Изложение основного материала. На основе результатов исследования предложены подходы и система показателей по осуществлению финансовой диагностики и оценки эффективности деятельности (операционной, финансовой, инвестиционной) хозяйствующих субъектов. Оригинальность и практическое значение исследования заключается в обосновании методического обеспечения финансовой диагностики ориентированной на управление стоимостью предприятий: методы менеджмента ЭВМ, системы показателей и критериев оценки экономически добавленной стоимости и эффективности деятельности. Bblвoдbl исследования. Использование методов менеджмента ЭВМ и финансовой диагностики позволяет определять отклонения внутренней стоимости рыночной и принимать соответствующие управленческие решения по инвестициям.

Ключевые слова:

финансовая диагностика, управление стоимостью, хозяйствующие субъекты, менеджмент на основе ожиданий (ЭВМ), рыночные ожидания, эффективность деятельности, стоимость.

Постановка проблеми. Створення i збереження вартості $є$ головною метою сталого розвитку господарюючих суб' єктів та ï конкурентоспроможності. Виходячи 3 цього актуальним є застосування адекватних методів оцінки ефективності управління вартістю підприємств 3 урахуванням ринкових очікувань. Результати досліджень ринків капіталу свідчать про наявність ринкових впливів, що проявляються в розходженнях між ринковою i фундаментальною вартістю. Фінансові показники ефективності діяльності підприємств розраховані на основі бухгалтерських даних не враховують ринкові очікування, щодо зміни вартості активів та доходності акціонерів. Відсутність такої інформації може призвести до зниження капіталізації суб'єкту господарювання та ризиків бізнесу. Для здійснення аналізу відхилень від ринкової вартості найбільш придатними $\epsilon$ перспективні методи фінансової діагностики результативності фінансового управління підприємств, зокрема, методи менеджменту на основі очікувань (ЕВМ).
Аналіз останніх досліджень та публікацій. Методи управління вартістю підприємств знаходиться у центрі уваги $[1,2$, $3,4,5]$ зарубіжних та вітчизняних вчених серед яких: Ю. Аніскін, І. О. Бланк, М. П. Бутко, Ю. Вебер, А. Дайлен, Н. Данілочкіна, С. В. Данилочкін, А. Долгофф, Р. С. Каплан, Т. Коупленд, Х.-Ю. Кюппер, Е. Майер, Р. Манн, Л. Птащенко, Т. Райхман, В. Сержанов, О. О. Терещенко, С. Фалько, Х.-Й. Фольмут, Д. Хан, Р. Хілтон, П. Хорват,Ч. Хорнгрен, Д. Шнайдер, Х. Штіглер, А. I. Шигаєв, К. Штайнле. Фінансова діагностика як інструмент управління підприємств отримала розкриття у наукових працях $[1,6,7]$ : I. Бланк, А. Вакуленко, В. Василенко, О. Гончарова, Т. Городня, О. Дейнеко, А. Даниленко, Н. Свдокімова, Л. Карась, М. Коротяєв, Л. Лігоненко, М. Мірошник, Н. Міценко, О. Олексюк, Р. Раппопорт, Б. Сербиновський, М. Скворцов, Е. Тарасов, М. Чумаченко, Г. Швиданенко, Р. Фатхудінова.

Проте, потребують подальшого дослідження та вирішення такі питання, що стосуються розвитку методичних засад фінансо- 
вої діагностики в управлінні вартістю підприємств зокрема: оцінювання впливу ринкових очікувань на вартість підприємства на основі методів менеджменту ЕВМ, обгрунтування системи показників фінансової діагностики ефективності за видами діяльності, узагальнення та модифікація результатів фінансової діагностики для прийняття управлінських рішень.

Мета статті. Обгрунтування методів менеджменту ЕВМ у фінансовій діагностиці ефективності управління вартістю суб'єктів господарювання .

Виклад основного матеріалу дослідження. В управлінні вартістю основна увага приділяється внутрішньому контексту діяльності підприємств. Раппапорт і Мабуссін вперше звернули увагу, що компанія повинна перевершувати очікування ринку і запропонували створення системи комунікацій 3 учасниками ринку капіталу, яка б дозволила виявляти інформаційні прогалини в прогнозах вартості компанії [7]. На основі їх підходу «інвестування в очікування», Коуплендом, Долгоффом доведено, що очікування сильніше впливають на сукупний дохід акціонерів і курсову вартість акцій компанії, ніж будь-який інший показник [4]. Оцінювання результативності діяльності господарюючих суб'єктів є основним завданням фінансового управління. Для оцінювання ефективності управління вартістю господарюючих суб'єктів необхідним є використання спеціальних методів фінансової діагностики. Дослідження еволюції фінансових показників, що характеризують діяльність підприємства в рамках концепції управління вартістю, свідчить, що система показників вимірювання вартості постійно змінюється [1, $2,4,5]$. На практиці для оцінки ефективності діяльності підприємств та прийняття управлінських рішень застосовуються різні інструменти: піраміда результативності (Perfomance Pyramid), призма результативності (Perfomance Prism), методи вартісно-орієнтованого управління (ValueBasedManagement) та менеджменту на основі очікувань (Expectations Based Management-EBM) [4]. Сучасне уявлення про критерії ефективності діяльності підприємств пов'язано 3 величиною i динамікою його вартості. 3 цією метою необхідним $є$ впровадження прогресивних методів фінансової діагностики.
Аналіз результатів дослідження дозволив зробити висновок, що в умовах посилення динамічності та не визначеності ринкового середовища функціонування підприємств доцільним $є$ здійснення фінансової діагностики результативності управління вартістю підприємств 3 використанням методів ЕВМ заснованих на ринкових очікуваннях. Підхід ЕВМ передбачає врахування динаміки очікувань всіх економічних агентів в управлінні як фундаментальної, так і ринкової вартості. Основними передумовами фінансової діагностики ефективності діяльності підприємств на основі методів ЕВМ є:

- систематичне відстеження очікувань всіх економічних агентів (менеджерів, аналітиків й інвесторів) в процесі управління фундаментальної вартістю i формування стратегії зовнішніх комунікацій та розробки стратегічного плану.

- необхідність оцінки внутрішнього i зовнішнього потенціалу створення вартості 3 метою узгодження фундаментальної й ринкової вартості. Основною причиною відхилень від ринкової вартості $\epsilon$ недостатність інформації про діяльність підприємства 3 урахуванням ринкових очікувань для потреб менеджменту.

- потреба акціонерів та економічних агентів у інформації щодо результативності управління вартістю для компенсації інвестиційного ризику протягом всього періоду прогнозування. Оцінка ефективності бізнесу грунтується на неокласичній моделі САРМ. Для нівелювання розходжень в оцінці вартості використовується показник економічного прибутку.

Метод ЕВМ базується на припущені, що при розробці та впровадженні моделі управління вартістю компанії менеджерам слід враховувати очікування економічних агентів щодо вільних грошових потоків. Це обумовлює систематичне відстеження очікувань всіх економічних агентів (менеджерів, аналітиків, інвесторів) в процесі управління внутрішньою й ринковою вартістю та формуванні зовнішніх комунікацій. Ключовим завданням $є$ фінансова діагностика результативності управління на основі використання методів менеджменту ефективності, що впливають на показник ЕВМ.

Структу ра фінансового управління в рамках ЕВМ наведена на рис. 1. 


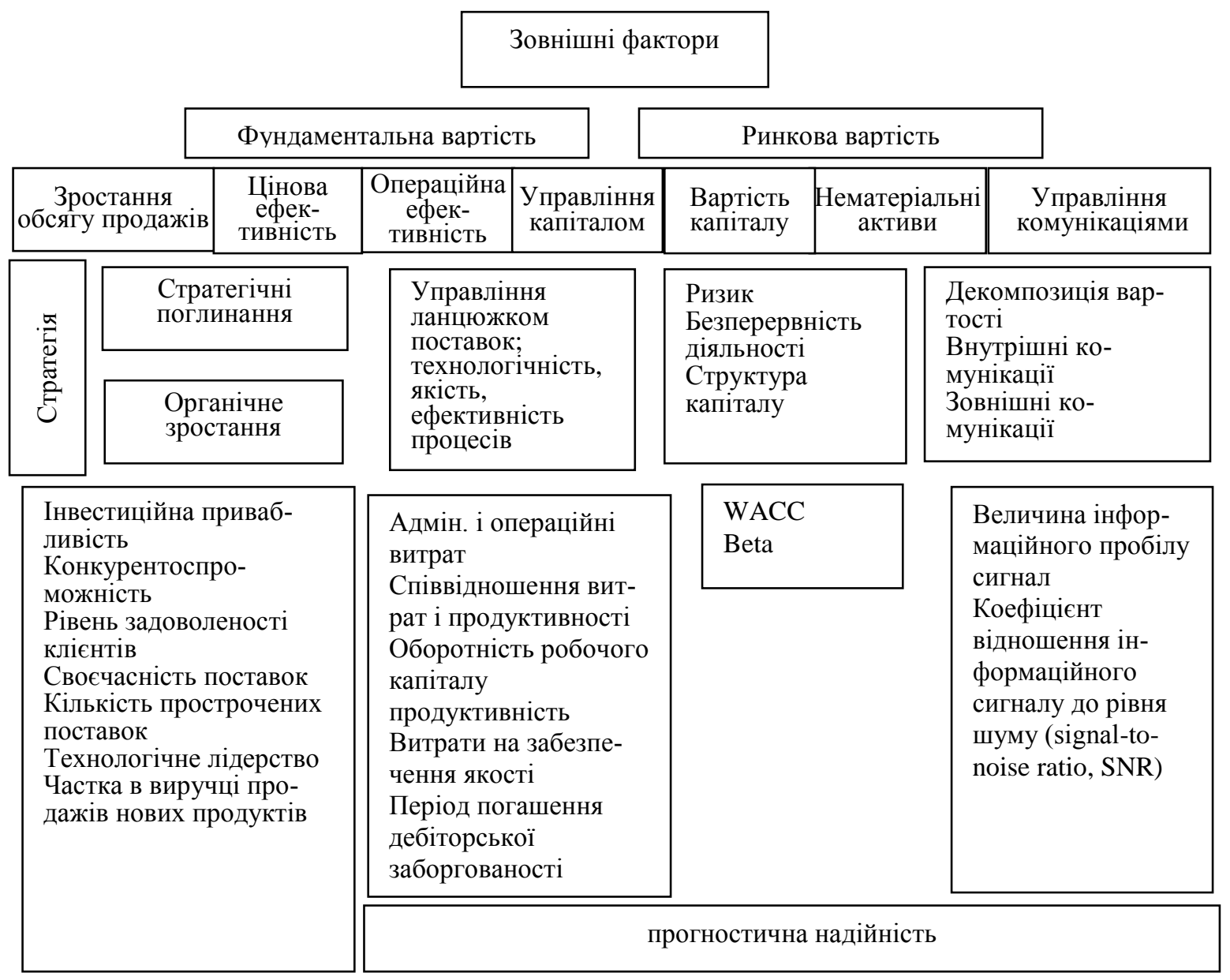

Рис. 1. Базовими концепціями фінансової діагностики є фінансова та ЕВМ. Джерело: розроблено авторам

Для побудови ефективної системи фінансової діагностики слід вирішити проблему методичного забезпечення зокрема обгрунтування системи показників. Системи показників фінансової діагностики обумовлюється:

1) метою та завданнями управління вартістю підприємств;

2) необхідністю прийняття рішень щодо вкладень нових інвестицій;

3) необхідністю виявлення та оцінювання резервів підвищення ефективності діяльності підприємств. Для здійснення фінансової діагностики результативності діяльності використовуються різні моделі, які розкриті в економічній літературі [4]: модель економічної доданої вартості -economic value added (EVA); модель добавленої акціонерної вартості - shareholders valueadded (SVA), CVA. Вказані моделі дозволяють пов'язувати критерії ефективності фінансових і інвестиційних рішень зі зміною вартості компанії та застосовуються для оцінки ефективності діяльності компанії, створення систем мотивації, поліпшення зовнішніх i внутрішніх комунікацій на підприємствах.

Методи EBM є найбільш придатними для здійснення фінансової діагностики ефективності діяльності підприємств за таких обставин:

1) забезпечення чіткого зв'язку між критеріями ефективності поточних операцій і вартістю підприємства [5]: ключові фактори вартості - фінансова діагностика результативності - оцінка вартості підприємств.

2) Показники, які відображають зміни акціонерного капіталу враховують динаміку ринкових очікувань, корелюють 3 прийняттям управлінських рішень i результатами оцінки ефективності менеджменту. Вартість підприємств розраховується на основі очікувань, які узагальнюється аналітиками на основі передачі певних сигналів ринку щодо майбутнього розвитку бізнесу. В якості параметра очікувань може виступати будь- 
яка змінна: прибуток фірми, валютний курс, наявний дохід [4]. Очікування можуть істотно впливати на динаміку результативності діяльності підприємств і прийняття управлінських рішень.

3) Необхідність формування інформації щодо ринкових очікувань та модифікації для здійснення фінансової діагностики 3 метою мінімізації відхилень в оцінках внутрішньої і ринкової вартості компанії. Ринкова вартість компанії відрізняється від фундаментальної оцінки (внутрішньої) у зв'язку 3 чим передбачається виявлення відхилень між очікуваннями менеджменту підприємства та ринковими очікуваннями;

4) Необхідність здійснення фінансової діагностики вартості підприємств 3 урахуванням очікувань на основі використання методу дисконтованого грошового потоку (DCF) для розробки фінансових прогнозів. Якщо оцінка внутрішньої вартості компанії відповідає ринковій вартості компанії, то необхідно здійснювати моніторинг внутрішніх i ринкових очікувань 3 метою забезпечення дохідності бізнесу на рівні не нижче вартості капіталу. Якщо різниця між оцінками велика, то необхідно виявити причини 3 метою їх уникнення або прийняти відповідні рішення щодо підвищення вартості компанії.

Показник на основі очікувань ЕВМ $\epsilon$ сполучною ланкою між заданими критеріями ефективності діяльності, системою ії̈ оцінки і досягнутими результатами. Він розраховується як різниця між фактичним i очікуваним економічним прибутком. $\mathrm{y}$ загальному вигляді показники фінансової діагностики результативності управління внутрішньої вартістю можна розмежувати за видами діяльності (операційної, фінансової, інвестиційної).

1) Показник ефективності операційної діяльності відображає можливий приріст економічної доданої вартості (EVA) за рахунок зростання рентабельності інвестованого капіталу та розраховується за формулою (1):

$$
\mathrm{EBM}=\left(\mathrm{ROIC}_{\text {факт }}-\mathrm{ROIC}_{\text {очік. }}\right) * \mathrm{I}_{\text {очік. }}
$$

На основі розмежування ROIC за моделлю Дюпон на фактори вартості можна визначити цільові нормативи (ключові показники) створення вартості за рівнями відповідальності.
2) Показник ЕВМ ефективності фінансової діяльності характеризує потенціал створення економічно доданої вартості за рахунок зниження вартості залученого капіталу необхідного для реалізації проекту (2):

$$
\mathrm{EBM}=\left(\mathrm{WACC}_{\text {фак }} \mathrm{T}-\mathrm{WACC}_{\text {очік }}\right) * \mathrm{I}_{\text {очік }} \text { ( }
$$

WACC використовується при прийнятті рішень щодо планування структури капіталу, оцінки вартості активів та вибору інвестиційних проектів [4]. При розрахунку очікуваної величини WACC власного и залученого капіталу враховується очікувана структура капіталу.

3) Показник ЕВМ ефективності інвестиційної діяльності характеризує потенціал створення економічної доданої вартості в результаті зростання (порівняно 3 очікуванням) капіталу на розвиток підприємств 3 урахуванням співвідношення фактичного рівня ROIC i WACC (3):

$$
\mathrm{EBM}=\left(\mathrm{ROIC}_{\text {факт }}-\mathrm{WACC}_{\text {факт }}\right) * \mathrm{I}_{\text {факт }}-\mathrm{I}_{\text {очік }} \text { (3) }
$$

На основі порівняння WACC й очікуваної дохідності інвестицій приймаються рішення щодо розробки i реалізації програми комунікації з інвесторами та вкладень в нові інвестиційні проекти. Створення вартості (згідно ЕВМ) виникає в наступних випадках:

1) якщо рентабельність інвестованого капіталу перевищує очікувану;

2) якщо рівень WACC нижче очікуваного;

3) якщо рентабельність нових інвестицій вище WACC.

Отже, врахування ринкових очікувань у фінансовому управлінні $\epsilon$ важливим елементом оцінки потенціалу зростання курсової вартості акцій компанії.

Висновки та перспективи подальших досліджень. Інструментом поліпшення комунікацій узгодженості зі стейкхолдерами на основі інформації щодо ринкових очікувань та перспектив бізнесу $є$ фінансова діагностика ефективності діяльності господарюючих суб'єктів. Причинно-наслідковий зв'язок між ефективністю операційної та фінансової діяльності й створенням нової вартості суб'єкта господарювання проявляється в процесі оцінки його очікувань фінансових результатів. Подоланню інформаційної асиметрії та уник- 
нення розходжень між фундаментальною і ринковою вартістю сприятиме діагностика внутрішнього й зовнішнього потенціалу створення вартості підприємств. Доведено, що методи менеджменту EBM $є$ найбільш придатними для фінансової діагностики та системного аналізу впливу ринкових очікувань на економічну додану вартість окремих видів діяльності з метою прийняття управлінських рішень щодо забезпечення дохідності бізнесу. Запропонована система показників оцінювання ефективності за видами діяльності підприємств надає можливість оцінити потенціал створення вартості та визначити цільові параметри за рівнями відповідальносTi.

Подальші дослідження будуть спрямовані на обгрунтування методичних положень щодо комплексної фінансової діагностики результативності управління підприємств.

\section{Література}

1. Контроллинг как инструмент управления предприятием / Е. А. Ананькина, С. В. Данилочкин, Н. Г. Данилочкина и др. ; под ред. Н. Г. Данилочкиной. - М. : ЮНИТИ, 2002. -279 c.

2. Horvath P. Controlling / Peter Horvath. [12 Auflage]. - Munchen, 2011. 848 p. doi: $10.15358 / 9783800644551$

3. Stewart B. The Quest for Value: a Guide for Senior Managers. New York: Harper Collins Publishers, 1991. - 800 p.

4. Коупленд, T. Expectations-Based Management. Как достичь превосходства в

Стаття надійшла

до редакції : 10.02.2019 p. управлении стоимостью компании / Т. Коупленд, А. Долгофф; [пер. Э.В. Кондуковой]. М. : Эксмо, 2009. - 384 с.

5. Kaplan $R$. Risk Management - The Revealing Hand / R. Kaplan A. Mikes // Journal of Applied Corporate Finance. - 2016. - № 28(1). - C. 8-18.

6. Бланк И. А. Управление прибылью / И. А. Бланк. - К. : «НИКА - Центр», 2000. $544 \mathrm{c}$.

7. Pannonopm B. $Ш$. Диагностика управления : практический опыт и рекомендации / В. Ш. Раппопорт. - М. : Экономика, 1988. - $127 \mathrm{c}$

\section{References}

1. Anankina, E. A. \& Danilochkina, S.V. (2002). Controlling as an enterprise management tool. Mosocow: UNITI, 279.

2. Horvath, P. (2011). Controlling. [12 Auflage]. Munchen, 848. doi: 10.15358/ 9783800644551

3. Stewart B. (1991). The Quest for Value: a Guide for Senior Managers. New York: Harper Collins Publishers, 800.

4. Copeland, T. \& Dolgoff, A. (2009). Expectations-Based Management. How to achieve excellence in cost management company / $\mathrm{T}$. Copeland, A. Dolgoff. Moscow: Eksmo, 384.

5. Kaplan, R. \& Mikes, A. (2016). Risk Management - The Revealing Hand. Journal of Applied Corporate Finance, № 28(1), 8-18.

\footnotetext{
Стаття прийнята

до друку: 29.03.2019 р.
}

Бібліографічний опис для цитування :

Свтушенко М. В. Методи менеджменту ЕВМ у фінансовій діагностиці ефективності управління вартістю суб’єктів господарювання / М. В. Свтушенко // Часопис економічних реформ. - 2019. № 1 (33). - С. 76-81. 